\title{
Hogyan lett Semmelweis Ignác S-jelenség?
}

\author{
Avagy megemlékezés Semmelweis halálának 156. épfordulójáról
}

\author{
Felkai Péter dr. \\ Debreceni Egyetem, Belgyógyászati Intézet, Anyagcsere Tanszék, Utazásorvostani Tanszéki Csoport, Debrecen
}

A tradicionális, Semmelweist illető állandó jelzőt, az „anyák megmentőjét” Rákosi Jenő használta a Budapesti Hirlapban először, amikor adakozásra szólította fel a fóváros lakosságát Semmelweis szobrának megalkotásához [1]. A hatásos epitheton ornans azonban így nem igaz. Sajnos Semmelweis az anyákat nem tudta mind megmenteni - csak azokat, akik bécsi és budapesti közkórházi főorvosi és egyetemi tanári múködése alatt az osztályára kerültek. Semmelweis Ignác 1865. augusztus 13-án, tehát 156 éve, a feltételezhetően embertelen bánásmód miatt, több sebból vérezve halt meg a brünnfeldi Alsóausztriai Kerületi Elmegyógyintézetben [2, 3], és sorsa kísértetiesen emlékeztet Széchenyi Istvánéra, aki 5 évvel azelőtt a döblingi elmegyógyintézetben halt meg, és halálának körülményei máig vitatottak. Bár Semmelweis halálának okát is hevesen vitatták a magyar orvostörténelem kutatói [4], a tény az, hogy a világon legismertebb magyar orvos nyomorult körülmények között halt meg. Valószínú, hogy a megfelelő kezelés elmulasztása és az embertelen bánásmód következtében beállott vérmérgezés miatt szégyellték magukat a bécsi hivatalos szervek, és emiatt tagadták meg 120 évig Semmelweis orvosi dokumentumainak kiadását [5]. Ne várjunk tehát kerek évfordulókra, hogy Semmelweis Ignácról megemlékezzünk: a kitüntetések átadásával egybekötött hivatalos ünnepléseken felül azt is nézzük meg, hogy milyen tanulságot hordoz ez a név, mit jelent ma a világnak, és gondolkozzunk el azon, hogy napjainkban, orvosi és tudományos munkánk során mennyire felelünk meg az elfogulatlan, elemző gondolkodás követelményének.

\section{Az új eszme}

Mint közismert, Semmelweis korszakalkotó megfigyelése az volt, hogy a gyermekágyi lázat nem az akkor uralkodó teóriának, a levegő közvetítette általános járványnak (epidémiának), hanem helyi fertőzésnek, endémiának tapasztalta meg, és a fertőzést a boncolás után a kézen maradt „bomlott szerves anyag”-nak tulajdonította, melyet ő és a szülő nőket vizsgáló vitt be a sebként tátongó

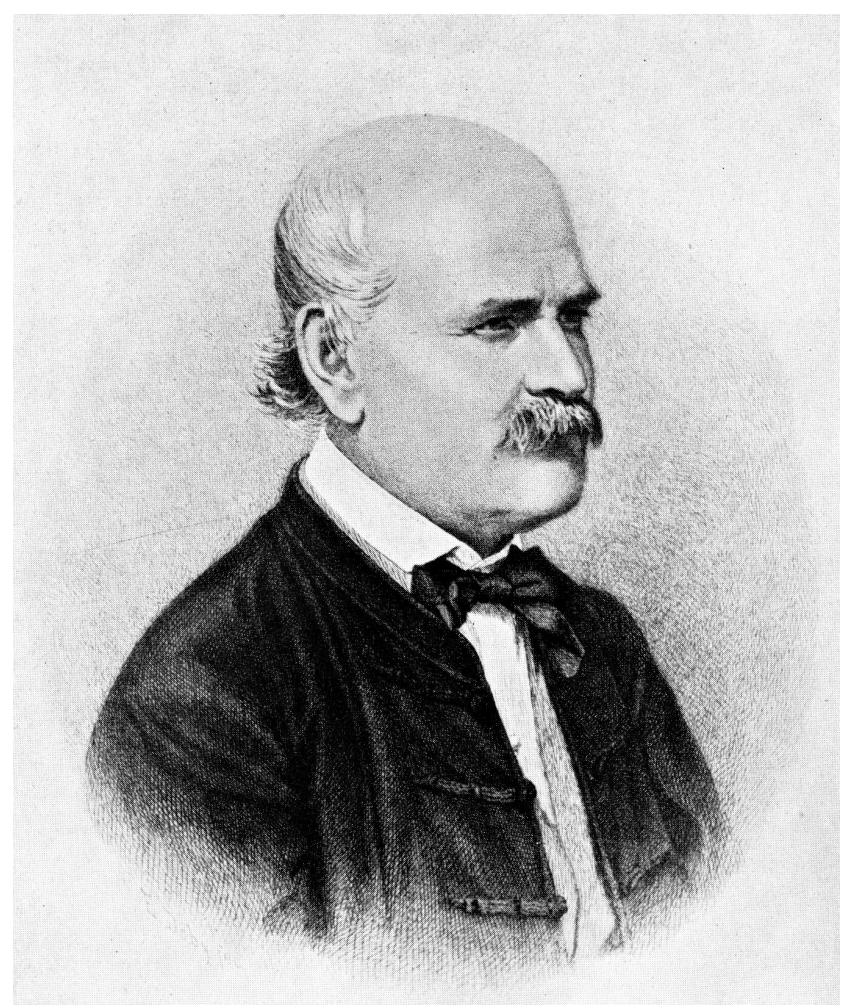

1. ábra Semmelweis közismert képe, Doby Jenő alkotása (a Medizinische Universität Wien, Bildarchiv tulajdona)

szülőcsatornába. Megfigyelését alátámasztotta - és ezt statisztikai módszerrel is bizonyította -, hogy a vizsgálat előtti klórmeszes vízzel való kézmosás a gyermekágyi halálozást praktikusan megszünteti. Semmelweis tragédiája nem csak abból állt, hogy felismerését nem fogadták el, és ezért majd' negyedszázadig még számtalan szülő nő fertőződött meg és hunyt el a gyermekágyi láz miatt. Helyzetét súlyosbította, hogy végül is a vita nem Semmelweis igazsága felett folyt, hanem tudománypolitikai játszmává vált az új és a régi bécsi iskola, a magyar-osztrák orvostársadalom és még a prágai tanszékre való pályázók között is [6]. Erre az utóbbira Semmelweis is pá- 
lyázott, de végül is volt fönökének, Klein professzornak a veje, Johann Baptist Chiari nyerte el az állást. Semmelweis igazának mikrobiológiai megalapozására csak Pasteur és Koch felfedezései által, az 1870-es évek végén került sor: ezután lassanként teret nyertek az aszepszis elvei a világon. Csendesen elfogadták igazságát világszerte, itt-ott persze egy kis sovinizmussal. A két világháború között Semmelweis ikonikus hőssé vált, filmek, regények és - természetesen - tanulmányok születtek életéről, felfedezéséről és haláláról. Az „anyák megmentője" halálának centenáriumán, az 1965-ös emlékévben nyitották meg egykori szülóházában a róla elnevezett Orvostörténeti Múzeumot. Ekkor sokan már nem magyarnak, hanem németnek szerették volna tekinteni, és ez a kisajátítás egészen korunkig ível [7]. Doby Jenő 1860-ban készített tollrajza, melyen Semmelweis közismert portréja látható ( 1 . ábra), a német Wikimedia kommentárja németnek láttatja [8]. Semmelweis híre elterjedt a világban: értekezések sokasága említi őt és elődeit is [9].

\section{A Semmelweis-jelenség}

A tudományos paradigmaváltás mindig nehézséggel jár. Ellenfelünk nyilvánvaló igazságának elismerése - hát még ha az mellesleg legyilkosozott bennünket - ma is ritka jelenség. Semmelweis megfigyelése és annak gyakorlati alkalmazása - elméleti háttér nélkül - nem egyezett (és ma sem egyezne) az ortodox „tudományos közlemények” követelményrendszerével. Pedig Semmelweis egyik bécsi protektora és az akkori vezető ausztriai orvosi újság, a Zeitschrift der K. K. Gesellschaft der Ärzte zu Wien főszerkesztője, Hebra, a bőrgyógyászat későbbi neves professzora Semmelweis felfedezését a klórmeszes kézmosásról két alkalommal is egyenesen az Edward Jenner által felfedezett oltás jelentőségéhez hasonlította $[10,11]$. Végül is Edward Jenner ugyanígy járt: korrekt megfigyelését a tehénhimlővel való oltás ártalmatlanságáról (az emberi himlővel való oltás helyett, mely kockázattal járt) az Angol Tudományos Akadémia, a Royal Society lapja, a Philosophical Transactions visszautasította, metodológiai hiányosságokra hivatkozva.

Semmelweis (és a többi meg nem értett tudós) eszméinek, a nyilvánvaló tényeknek az automatikus elutasítását mindenféle meggondolás vagy kísérlet nélkül - ezt a (rendszerint a tudomány szaktekintélyeitől jövő) reflexet nevezik ma világszerte Semmelweis-, avagy S-reflexnek. A fontos tudományos tények felfedezését jutalmazás helyett büntetéssel sújtják - ezt a paradoxont Semmelweis példáján keresztül világítja meg Robert Anton Wilson amerikai pszichiáter az 1979-ben megjelent „Az élet játszmája” címú könyvben, és „Semmelweis-reflexnek” nevezte el [12]. Így Semmelweis sorstársai közé sorolhatjuk Giordano Brunót is, akit tanai miatt megégettek. Galileivel is visszavonatták tanát. De a reflex áldozatai közé sorolhatjuk az amerikai Dean Ornisht, a szívbetegségek és a helyes életmód közötti összefüggés megfigye- lőjét, vagy Barry Marshallt, aki baktériumtenyészet megivásával demonstrálta tételének igaz voltát [13]. Talán már az S-reflexnek köszönhető, hogy a két amerikai tudós végül megfigyeléseit a gyakorlatba is átültethette, sőt munkájukat a legmagasabb fórumokon is elismerték. Hasonló igaztalanságok kiküszöbölésére az USA-ban még társaságot is alapított három kutatóorvos 2003-ban, Semmelweis Society International néven - de a társaság, úgy tünik, csődbe ment [14].

A Semmelweis-reflexet (vagy ahogy gyakran emlegetik: az S-jelenséget), ezt a nem fiziológiai, hanem lélektani reflexet sok kritérium jellemzi, így például az, hogy az állítás nem illeszthető be a kor tudományos képébe, azt érdemi vizsgálat nélkül elutasítja a tudományos ortodoxia, az állítás/megfigyelés/felfedezés szerzőjét retorzió éri, stb. [15].

Semmelweis a maradványai negyedik kihantolását követően, 1963-ban került végső (?) nyughelyére, megtisztogatott csontjait egy múanyag tömbben befalazták a Semmelweis-ház udvarának Várhegy felé eső oldalába [16]. Talán ezért adta hozzá Csörgő Tamás professzor az S-reflex ismertetőjeleihez a „Méltatlan temetés - amit díszes újratemetés(ek) követ(nek)" kritériumot.

Semmelweis - ma úgy mondanánk - megosztó személyiség volt. De makacs és harsány kiállása az igaza mellett a mai napig nem hagyja közömbösen az orvostudományt: egy tanulmány 55 oldalon keresztül sorolja fel a róla megjelent szakközleményeket [17]. Semmelweis Ignác tehát felfedezésével nem jutott ugyan sokra, még gyalázatos körülmények között elszenvedett halála sem rázta meg az akkori orvostársadalmat, sem külföldön, sem belföldön. Csak miután a mikrobiológia megszületésével és eredményeinek hasznosításával bebizonyosodott, hogy milyen egyszerúen lehet az orvosi tevékenységgel együtt járó halálos fertőzést legyőzni, akkor döbbent rá a szakma a magyar orvos nagyságára. Kevesen voltak azok, akik a gyakorlatban is kipróbálták és bevezették Semmelweis módszerét. Közülük is kiemelkedik Gustav Adolf Michaelis kieli nőgyógyászprofesszor, aki Semmelweis módszerét alkalmazta, és azzal saját klinikáján a halálozási arányt drasztikusan csökkentette. Ekkor, felelősséget érezve a sok, keze alatt meghalt szülő nőért (köztük unokahúgáért), öngyilkos lett [18].

Napjainkban, főleg az angolszász irodalomban, bőven találunk hivatkozást az S-reflexre [19]. Filmet is forgattak a reflexről: a Jim Berry rendezte „Semmelweis” címút [20]. A fogalom megjelent a magyar szakirodalomban is, éppen az Orvosi Hetilap adott róla hírt [21]. A reflexről sok tudományos értekezés is született, rámutatva arra, hogy a reflex káros hatását el lehet kerülni, ha az új gondolatok megfelelő és elfogadott formában, szigorú tudományos kritikával kerülnek a bírálók elé [22]. Csakhogy az S-jelenségnek éppen az a kiváltója, hogy kívül áll az elfogadott paradigmákon. Az S-jelenség csapdáit el lehet kerülni, néhány alaptechnika alkalmazásával [15]. 
Az alatt a 30 év alatt, míg ráébredtek a szülőszobai aszepszis életmentő fontosságára, vajon hány nő halt bele a világon a gyermekágyi lázba? Ezeket nem tudta megmenteni Semmelweis. Egyvalamit azonban - bár akaratán kívül - Neki köszönhetünk: azt a tanulságot, hogy mert egy ötlet, eszme vagy jelenség új, és magyarázata nem illik bele az addig elfogadott tudományos nézetekbe, először meg kell vizsgálni, mielőtt elvetnénk. Persze az örökmozgó feltalálóit nem sorolnám ide. A jelenség elkerülésére különösen az orvoslásban mérvadó, hivatalban lévő szaktekintélyeknek kell gondosan ügyelniük: egy-egy diagnózis felállításának nehézségét még növelheti a sablonokban való gondolkodás [23]. Semmelweis öröksége tehát olyan tanulság, melyet ma már többé-kevésbé igyekeznek a tudományos életben is szem előtt tartani. Semmelweis példája ma is időszerü, mert csak tudományos módszerekkel bebizonyított tényekkel lehet a közvélemény elé állni. És ezt nemcsak a tudósoknak, hanem a média múvelőinek is illene megszívlelniük.

\section{Köszönetnyilvánítás}

A szerző köszönetét fejezi ki $d r$. Csörgő Tamásnak, az Európai Akadémia tagjának, az MTA doktorának, dr. Kapronczay Károly c. egyetemi tanárnak, az MTA doktorának és dr. Bálint Péter Vince c. egyetemi tanárnak.

\section{Irodalom}

[1] Rákosi J. Savior of mothers. [Anyák mentője.] Budapesti Hírlap 1894. április 22. [Hungarian]

[2] Benedek I. Semmelweis and his age. [Semmelweis és kora.] Gondolat Kiadó, Budapest, 1967. [Hungarian]

[3] Gortvay Gy, Zoltán I. Semmelweis, his life and works. [Semmelweis élete és munkássága.] Akadémiai Kiadó, Budapest, 1966. [Hungarian]

[4] Antall J. Semmelweis, his illness and death. Introduction to a debate on the public-made Vienna medical case history. [Semmelweis betegsége és halála - bevezetés a nyilvánosságra hozott bécsi kórtörténet alapján kialakult vitához.] Orvostört Közl. 1978; 83-84(24 No 1-2): 9-13. [Hungarian]

[5] Benedek I. Letter of István Benedek to György Silló-Seidl. In: Benedek I. About Semmelweis' disease and on the actuality of Semmeweis' thesises. [Benedek István levele Silló-Seidl Györgyhöz. In: Benedek I. Semmelweis betegségéről és a semmelweisi tanok időszerúségéről.] Magyar Tudománytörténeti Intézet, Budapest, 2015. [Hungarian]

[6] Lesky, E. Ignaz Philipp Semmelweis und die Wiener medizinische Schule. Böhlau in Komm., Wien, 1964.

[7] Andreas W, von Scholz W. (eds.) Die großen Deutschen. Neue Deutsche Biographie. Propyläen-Verlag, Berlin, 1935.

[8] Available from: https://hu.wikipedia.org/wiki/A_magyar_ eg\%C3\%A9szs\%C3\%A9g\%C3\%BCgy_napja\#/media/ F\%C3\%Aljl:Ignaz_Semmelweis.jpg [accessed: June 22, 2021].

[9] Carter KC. Semmelweis and his predecessors. Med Hist. 1981; 25: 57-72.

[10] Hebra F. Höchst wichtige Erfahrungen über die Ätiologie der in Gebäranstalten epidemischen Puerperalfieber. Zeitschrift der K. K. Gesellschaft der Ärzte zu Wien 1847; 4(2): 242-244.

[11] Hebra F. Fortsetzung der Erfahrungen über die Ätiologie der in Gebäranstalten epidemischen Puerperalfieber. Zeitschrift der K. K. Gesellschaft der Ärzte zu Wien 1848; 5(1): 64-65.

[12] Leary T, Wilson RA. The game of life. New Falcon Publications, Phoenix, AZ, 1993.

[13] York EP, Brown T. The price they paid. J Community Hosp Internal Med Perspect. 2015; 5: 26436.

[14] Available from: https://www.zoominfo.com/c/semmelweissociety-international/79921931 [accessed: July 24, 2021].

[15] Csörgó TJ. János Bolyai and the Semmelweis reflex. [Bolyai János és a Semmelweis reflex.] 10th Bolyai-Gauss-Lobachevsky conference on non-Euclidean geometry and its applications. Gyöngyös, 2017. augusztus 20-26.

[16] Papp Z. Five funerals of Ignaz Semmelweis. In: Rosivall L. The 200 years of Semmelweis. [Semmelweis Ignác ötszöri temetése. In: Rosivall L. Semmelweis 200 éve.] Semmelweis Kiadó, Budapest, 2018; pp. 169-177. [Hungarian]

[17] Murphy FP. Ignaz Philipp Semmelweis (1818-1865), an annotated bibliography. Bull Hist Med. 1946; 20: 653-707.

[18] Grigorieva KN. Gustav Adolf Michaelis (1798-1848). Obstetr Gynecol Reprod. 2019; 13: 384-387.

[19] Mortell M, Balkhy HH, Tannous EB, et al. Physician 'defiance' towards hand hygiene compliance: is there a theory-practiceethics gap? J Saudi Heart Assoc. 2013; 25: 203-208.

[20] Berry J. Semmelweis. Available from: http://www.scienceandfilm.org/projects $/ 7 /$ semmelweis [accessed: June 27, 2021].

[21] Bálint P, Bálint G. The Semmelweis reflex. [A Semmelweisreflex.] Orv Hetil. 2009; 150: 1430. [Hungarian]

[22] Gupta VK, Saini C, Oberoi M, et al. Semmelweis reflex: an ageold prejudice. World Neurosurg. 2020; 136: el19-e125.

[23] Howard J. Semmelweis reflex. In: Cognitive errors and diagnostic mistakes. Springer Nature, Cham, 2019.

(Felkai Péter dr., Budapest, Szentendrei út 301., 1039 e-mail: peter.felkai@soshungary.hu)

A cikk a Creative Commons Attribution 4.0 International License (https://creativecommons.org/licenses/by/4.0/) feltételei szerint publikált Open Access közlemény, melynek szellemében a cikk bármilyen médiumban szabadon felhasználható, megosztható és újraközölhetö, feltéve, hogy az eredeti szerző és a közlés helye, illetve a CC License linkje és az esetlegesen végrehajtott módosítások feltüntetésre kerülnek. (SID_1) 